\title{
Testosterone undecanoate and depo medroxyprogesterone acetate induced azoospermia through increased expression of spermatogenic cell caspase 3
}

\author{
Nukman Moeloek ${ }^{1}$, Asmarinah $^{1}$, Nurjati Chairani Siregar ${ }^{2}$, Syafruddin Ilyas ${ }^{3}$
}

\begin{abstract}
Abstrak
Telah dilakukan penelitian tentang efek pemberian kombinasi testosteron undekanoat (TU) yang merupakan androgen dengan masa aktif lama dan depo medroksiprogesteron asetat (DMPA) dalam penekanan konsentrasi sperma tikus secara in vivo melalui peningkatan aktivitas protein caspase 3 sel spermatogenik. Tikus Sprague Dawley dewasa diberi TU 2,5 mg+DMPA 1,25 mg yang telah diketahui mempercepat pengurangan produksi testosteron oleh testes dan menimbulkan azoospermia dalam 12 minggu. Sel sperma yang positif caspase 3 meningkat dibandingkan dengan kontrol setelah 6 minggu penyuntikan dan tetap meningkat sampai 60 minggu. Immunohistokimia caspase 3 memperlihatkan bahwa spermatosit lebih banyak yang positif caspase 3. Aktifitas ekspresi caspase-3 berlokasi pada bagian inti sel germinal baik pada testis kontrol maupun pada perlakuan. Immunohistokimia juga memperlihatkan adanya peningkatan ekspresi yang signifikan dari caspase 3 pada inti sel germinal selama pemberian TU+DMPA pada tikus (453,90土84,88 sel/200 tubulus seminiferus). Kemudian, kandungan caspase 3 meningkat secara signifikan pada inti sel germinal seperti spermatogonia, spermatosit, dan spermatid. Sehubungan dengan itu, hasil ini dapat menyimpulkan bahwa azoospermia terjadi karena adanya pengurangan testosteron intratestikular yang berhubungan dengan ekspresi caspase 3 dan diduga bahwa peningkatan ekspresi caspase 3 pada inti mungkin terlibat dalam penurunan produksi sperma. (Med J Indones 2008; 17: 149-56)
\end{abstract}

\begin{abstract}
The administration of a combination of testosterone undecanoate (TU, a long-acting androgen) and depo-medroxyprogesterone acetate (DMPA) were investigated in term of suppression of rat sperm concentration in vivo to azoospermia through increasing activity of spermatogenic cell caspase 3. Adult Sprague Dawley rats received TU and DMPA of $2.5 \mathrm{mg}$ and $1.25 \mathrm{mg}$, respectively, a regimen known to rapidly reduce intra testicular testosterone and to produce azoospermia within 12 weeks. Caspase 3 positive sperm cells increased compared with control levels during 6 weeks post-injection and increased further through 60 weeks. Immunohistochemistry for caspase 3 revealed that spermatocytes represented the predominant caspase 3 positive germ cells. Modest immunoreactivity for caspase-3 was localized to nuclear region of the germ cells of control and treated testes. Immunohistochemistry study revealed significantly increased caspase-3 expression in nuclei of germ cells during administration of TU+DMPA to rats. Additionally, the caspase 3 content was significantly increased in germ cells during rats were administered TU+DMPA (453.90 \pm 84.88 cells/200 seminiferous tubules) and caspase 3 significant increase in immunoreactivity was localized to the nuclei of spermatogonia, spermatocytes, and spermatids. Taken together, these results indicated that azoospermia due to reduced intratesticular testosterone concentration was caspase-3 activation dependent and suggested that the increase in active caspase-3 in the nucleus may be involved in the induction of decreased sperm production. (Med J Indones 2008; 17: 149-56)
\end{abstract}

Keywords: TU, DMPA, sperm concentration, germ cells

A number of approaches to male hormonal contraception using testosterone $(\mathrm{T})$ esters have been widely investigated. ${ }^{1}$ In several studies, an androgen

1 Department of Medical Biology, Faculty of Medicine, University of Indonesia, Jakarta, Indonesia

2 Department of Anatomic Pathology, Faculty of Medicine, University of Indonesia/Dr. Cipto Mangunkusumo Hospital, Jakarta, Indonesia

3 Department of Biology, Faculty of Mathematics and Natural Sciences, University of North Sumatra, Medan, Indonesia ester has been administered to both consistently suppress gonadotropins and serve as androgen replacement. Azoospermia could be achieved in $80 \%$ of Chinese men $^{2}$ and $94.7 \%$ to $100 \%$ of Indonesian fertile men $^{3}$ by administration of 8 weeks and 6 weeks interval, respectively. Results from several studies suggested a direct relationship between sperm suppression and gonadotropin suppression. ${ }^{4}$ Profound suppression of spermatogenesis can be achieved by the addition of a progestin to an androgen, to act synergistically on the hypothalamus and pituitary to suppress gonadotropin 
secretion. ${ }^{5}$ Intratesticular testosterone was decreased by suppression of gonadotropin secretion. In fact, caspase 3 activation has been shown to occur in rat germ cells by 1 week during in vivo reduction of intratesticular testosterone, and internucleosomal DNA cleavage in germ cells continued increasing through the subsequent 3 weeks. ${ }^{6}$ In a study, Kim et al, ${ }^{6}$ examined the roles of caspase-3 and caspase-activated deoxyribonuclease (CAD) activation in relation to the apoptotic death of germ cells. They showed that testosterone withdrawal resulted in spermatocyte apoptosis, and that this was correlated to activation of caspase- 3 as well as increased CAD protein expression. Additionally, immunohistochemical analysis revealed that both caspase- 3 and CAD were localized in the nuclei of spermatocytes at the time of apoptosis. Taken together these results suggest that spermatocyte apoptosis, resulting from reduced intratesticular testosterone, is mediated by caspase- 3 activation and CAD.

The aim of this study was to evaluate the expression of germ cells' caspase-3 in long term injections of testosterone undecanoate and depo medroxyprogesterone acetate on rats.

\section{METHODS}

\section{Animals}

One hundred and forty rats (Sprague Dawley, BPOM Depkes RI) were used for this study. Animals were given water and chow (rat chow no. PB551) ad libitum. The animal room climate was kept at a constant temperature $\left(20-23^{\circ} \mathrm{C}\right)$ at $35-70 \%$ humidity with a 12 -h alternating light-dark cycle.

\section{Androgen/progestin preparation}

Injectable testosterone undecanoate (TU) was provided by Schering A G Germany. in ampoules containing 1000 $\mathrm{mg}$ of TU in $4 \mathrm{~mL}$ castor oil (Nebido ${ }^{\circledR}$ ). The same batch of TU was used throughout the study. Depo medroxy progesterone acetate (DMPA) was manufactured in Jakarta, as an aqueous suspension and packaged in 3-ml vials containing 150 mg DMPA (Depo Geston ${ }^{\circledR}$ ).

\section{Study design}

A prospective, monosentric, controlled, and completely randomized design was used. The study consisted of 4 phases: a pretreatment phase lasting at least 4 weeks, a suppression phase lasting 24 weeks, maintenance phase lasting 36 weeks and a recovery phase lasting 12 weeks.

Pretreatment phase: during this period the rats were provided 3 solvent samples each at the left and right cauda epididymis.

Suppression and maintenance phase: at completion of pretreatment period, the 40 rats were randomly assigned to treatment and control group (20 subjects in each group).

The treatment group was given i.m. TU $2.5 \mathrm{mg}$ (every 6 weeks) plus DMPA $1.25 \mathrm{mg}$ every 12 weeks during the 24 weeks of suppression phase and 36 weeks of the maintenance period.

Recovery phase: during the recovery phase, every 6 weeks for 12 weeks, the rats underwent physical and sperm concentration examinations.

\section{Immunohistochemistry for caspase 3}

Testes from rats were fixed in Bouin's fixative (saturated picric acid:formaldehyde : acetic acid in the ratio of 15:5:1). Tissues were processed by standard procedures. Brief post-fixation wash and dehydration in graded ethanol $(70-100 \%)$ was followed by paraffin embedding. Five $\mu \mathrm{m}$ sections were cut with a microtome and transferred to slides. Fixed sections were deparaffinized and heated in citrate buffer 93$98^{\circ} \mathrm{C}$ for 20 minutes, then cooled 20 minutes at room temperature. Blocking of endogenous peroxidase activity was done with $0.3 \% \mathrm{H} 2 \mathrm{O} 2$ in PBS for 10 minutes, and nonspecific binding was prevented by soaking in 1\% BSA (Bovine Serum Albumin) for 30 min. Anti-caspase 3 primary antibody (C8487 Sigma - active antibody produced in rabbit) (1:750 dilution in $1 \%$ BSA) incubation was carried out at $4{ }^{\circ} \mathrm{C}$, for 16 hours, followed by incubation in Envision ${ }^{+}$dual link (secondary Ab, DKO.K406511) at $37^{\circ} \mathrm{C}$ for 30 minutes. After washing, color was developed with a diaminobenzidine kit and sections were counterstained in Mayer's hematoxyline for 30 seconds, soaked in $0.037 \mathrm{M}$ ammonia water for 1 minute, dehydrated, and mounted in entelan (modified from method of Cui et al.). ${ }^{7}$

The specimens were examined under the microscope. For each rat 200 seminiferous tubules were examined, and the number of caspace 3 positive germ cells per 200 seminiferous tubules were counted and noted. 


\section{Statistical analysis}

For quantitative data, means and standard errors of the means (SEMs) were measured. Then, one-way ANOVA, followed by post hoc test (software package, SPSS 10.01) were used to determine differences across time. Mann Whitney test was used to determine differences between 2 groups. Sperm concentration data were $\log$ transformed before analysis. Correlation of sperm concentration with caspase 3 positive germ cell number was analyzed using Spearman's rho test and regression analysis. $P<0.05$ was considered to be significant.

This study was approved by Animal Care and Use Committee, Primate Research Center - Bogor Agricultural University.

\section{RESULTS}

\section{Caspase 3 positive germ cells after TU+DMPA injection of rats}

To examine the possible involvement of caspase 3 in TU+DMPA-induced azoospermia, the timing of the presence of caspase 3 positive germ cells in relationship to TU+DMPA injection was studied by immunohistochemistry (Figure 1). Means of caspase 3 positive germ cells in treated group were gradually increased during the time between the first and end of regimen, and a significant increase was found at the $6^{\text {th }}$ week of the treatment period when compared with pretreatment values. Mean caspase 3 positive germ cells were maintained at very high levels throughout the 60 weeks of the treatment period (Figure 1). There was a trend toward a more sustained increase of caspase 3 positive germ cells in the treatment compared to the control group, and the difference was significant $(P<0.05)$. Germ cells started to recover during the recovery period (when TU+DMPA injection was stopped). By the $12^{\text {th }}$ week of the recovery period, mean caspase 3 positive germ cells in the treated group had returned to the normal reference range (8.20 $\pm 2.13 / 200$ seminiferons tubules), and there was no significant $(P>0.05)$ difference in this parameter when values at this time point were compared with pretreatment caspase 3 positive germ cells in untreated and treated group.

\section{Location of caspase 3 in germ cells in rats receiving TU+DMPA injection}

Caspase 3 immunohistochemistry were used to further examine the location of TU+DMPA-induced caspase 3 expression in germ cells (Figure 2). Figure 2A $\square$ represents a germ cell in rat testes that were caspase 3 negative. Figure $2 \mathrm{~A}-\mathrm{H}-$ represent the cells that showed evidence of caspase 3 immunoreactivity in the nuclei.

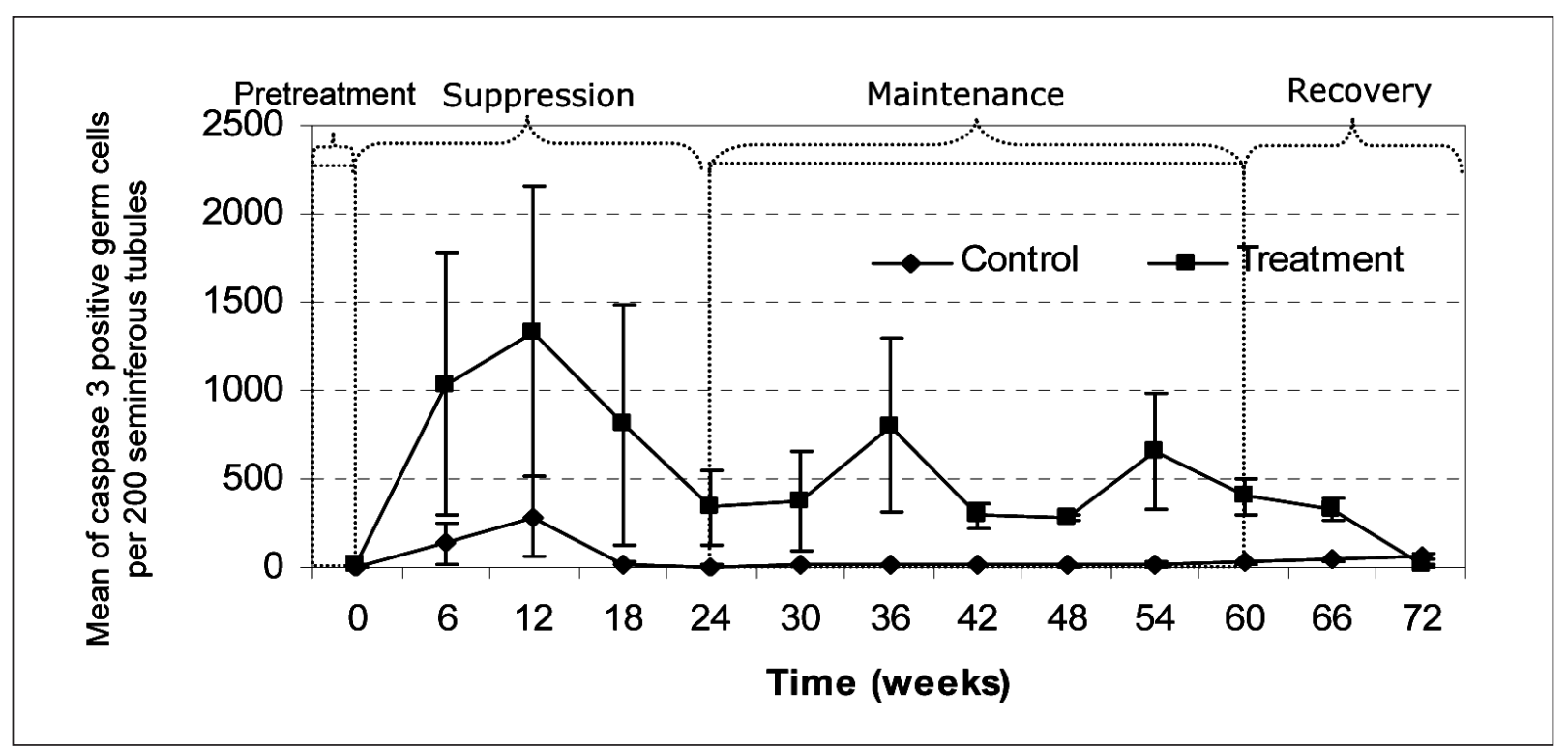

Figure 1. Caspase 3 positive germ cells per 200 seminiferous tubules in each time during the study. Values are expressed as the mean \pm SEM. 

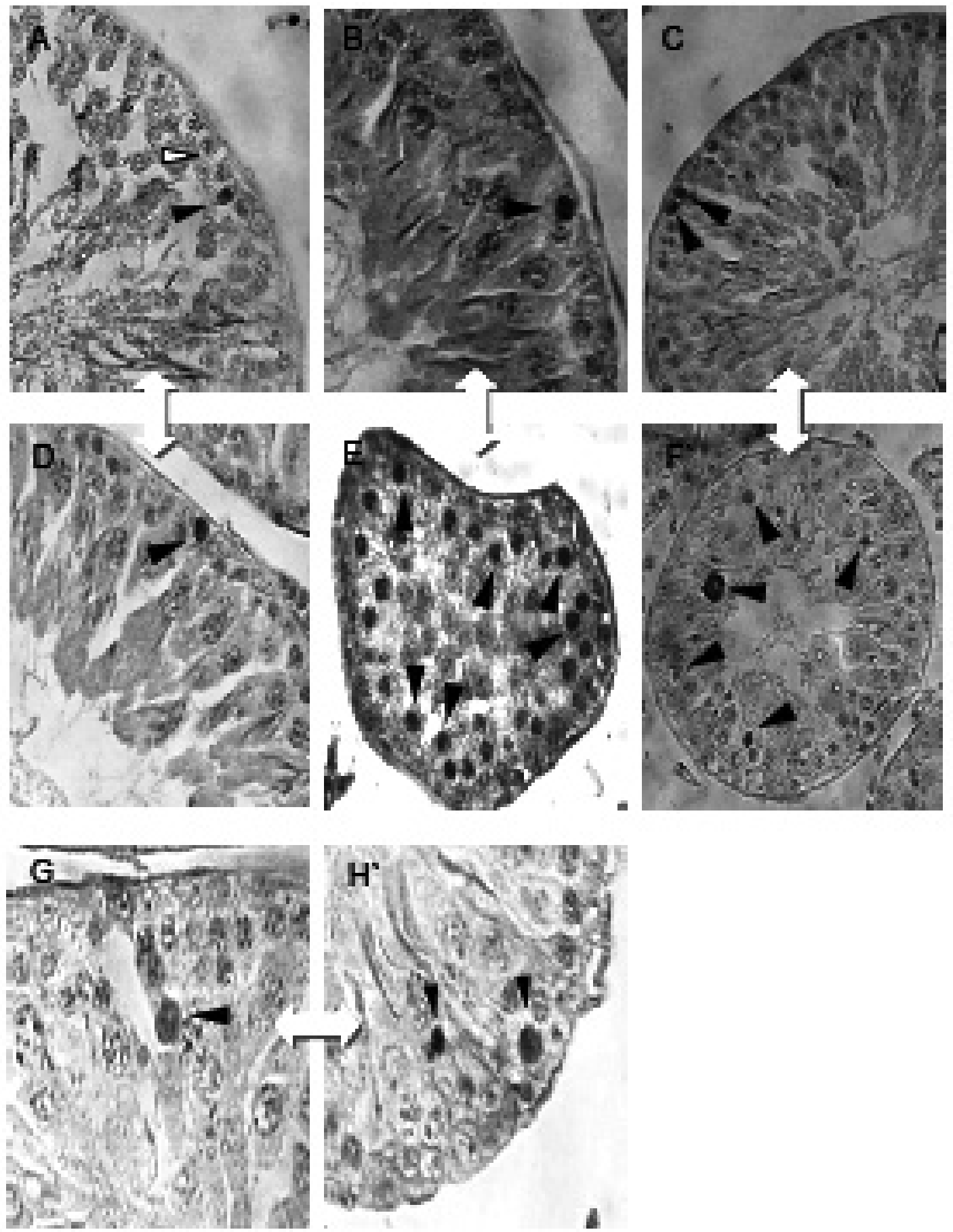

Figure 2. Location of caspase 3 in germ cells.

$A \& D$ : pretreatment phase (A: control, D: treatment), $B \& E$ : suppression phase (B: control, E: treatment), $C \& F$ : maintenance phase (C: control; $F$ : treatment) and $G \& H$ : recovery phase (G: control; $H$ : treatment). 


\section{Sperm concentration}

Proportion of the rats and time for achieving azoospermia or severe oligozoospermia $(\leq 3 \mathrm{million} / \mathrm{mL})$ during the study period in treatment group are shown in Figure 3. Azoospermia or severe oligozoospermia was achieved at week-24 and maintained in all rats except in 1 rat, where sperm rebound occurred (sperm concentrations were $16.33 \pm 1.53$ ) at week-54. There was a trend toward a sustained suppression of spermatogenesis in the treatment compared to the control group, and the difference was significant $(P<0.05)$. Spermatogenesis started to recover during the recovery period, though recovery of spermatogenesis was delayed and azoospermia was maintained for an additional 6 weeks after cessation of the maintenance period. By the $12^{\text {th }}$ week of the recovery period (at week-72), mean sperm concentration in the treated group had returned to the normal reference range (109.47 \pm 27.52 million/ $\mathrm{mL})$, and there was no significant difference $(P>0.05)$ in this parameter when values at this time point were compared with sperm concentrations in control group (Figure 4).

\section{Correlation between Sperm concentration vs Caspase 3 at treatment group}

Data of treatment group showed that sperm concentration was significantly associated $(P<0.05)$ with the presence of caspase-3-positive germ cells (Figure 5).

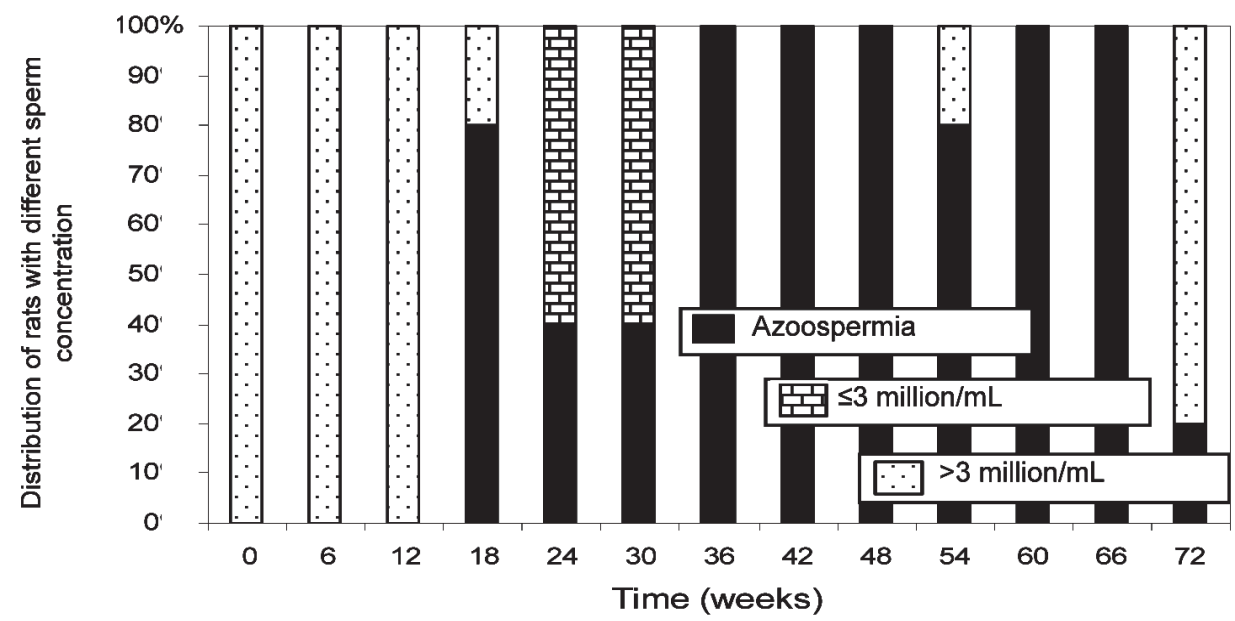

Figure 3. Proportion of treated rats with different sperm concentration per time point of the study

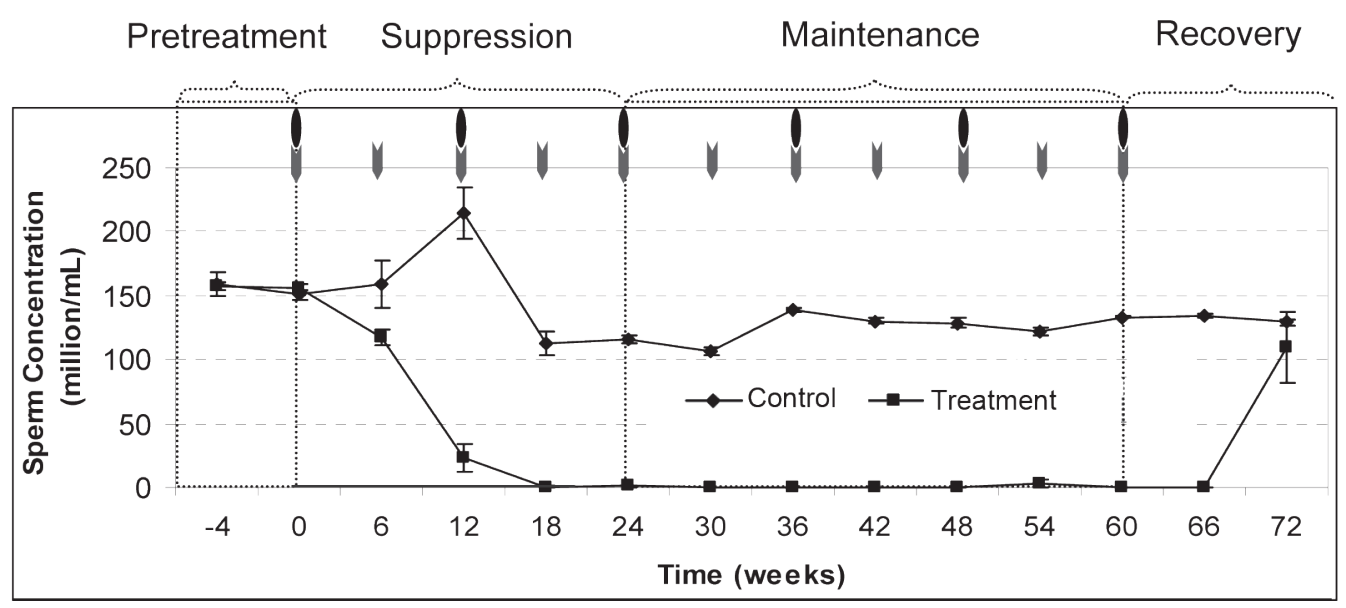

Figure 4. Mean sperm concentrations in each group during the study. Values are expressed as the mean \pm SEM in log scale. Arrows indicate hormone injections 
Table 1. Correlation between Sperm concentration vs caspase 3 positive germ cells

\begin{tabular}{|c|c|c|c|c|}
\hline & & & Sperm Concent. & Caspase 3 \\
\hline \multirow[t]{6}{*}{ Spearman's rho } & Sperm Concent. & Correlation Coefficient & 1.000 & $-.522 * *$ \\
\hline & & Sig. (2-tailed) & & 0.006 \\
\hline & & $\mathrm{N}$ & 26 & 26 \\
\hline & Caspase 3 & Correlation Coefficient & $-.522 * *$ & 1.000 \\
\hline & & Sig. (2-tailed) & 0.006 & \\
\hline & & $\mathrm{N}$ & 26 & 26 \\
\hline
\end{tabular}

** Correlation is significant at the .01 level (2-tailed).

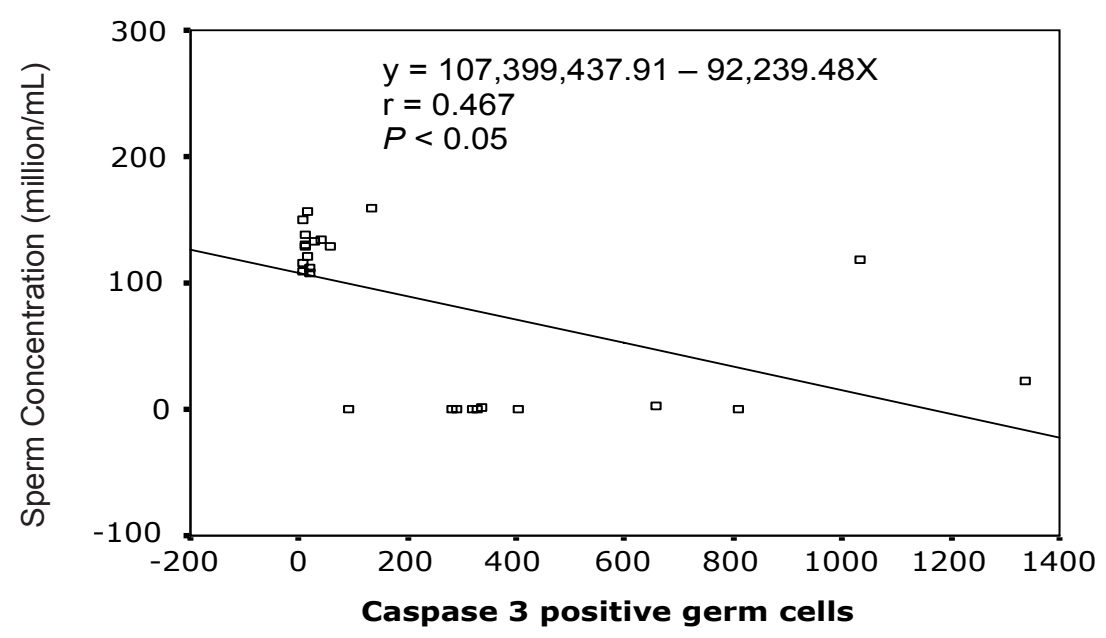

Figure 5. Regression diagram of the number of caspase 3 positive germ cells vs sperm concentration

\section{DISCUSSION}

This is the first study to evaluate the expression of caspase 3 in spermatogenic cells in long term repeated injections of testosterone undecanoate and depo medroxyprogesterone acetate on rats. Caspase 3 positive spermatogenic cells increased significantly during TU+DMPA long-acting injection from the $6^{\text {th }}$ to $60^{\text {th }}$ week (Figure 1). Caspase 3 positive germ cells in treatment group $(453.90 \pm 84.88$ cells $/ 200$ seminiferous tubules) differed significantly $(P<0,05)$ in comparison with control (50.13 $\pm 18.46 / 200$ seminiferous tubules). Therefore, long term and repeated TU+DMPA injections might induce the expression of caspase 3 in germ cells.

The increased caspase 3 expression might be due to reduced intratesticular testosterone in consequence of long term repeated injections of TU+DMPA that caused a decrease in LH and Leydig cells. However, the exact mechanism is unclear. This research results provided more evidence for the role of hormone as exogenous factor in germ cell caspase 3 expression. Said et al., ${ }^{8}$ and Tesarik et al. ${ }^{9}$ explained that reduced intratesticular testosterone could influence caspase 3 expression, and then caspase 3 activated deoxyribonuclease (CAD) in the nucleus that might induce germ cell apoptosis.

Caspase 3 expression in suppression and maintenance phases differed significantly with pretreatment and recovery phases (Figure 1). These results had proven that long term and repeated injections of TU+DMPA had an effect on caspase 3 expression in germ cells. In comparison with control, the treatment group showed significant differences $(P<0.05)$ only in suppression and maintenance phase. However, compared to the $1^{\text {st }}$ six weeks of pretreatment phase, caspase 3 expression in recovery phase was still higher $(P<0.05)$. Long term and repeated injections of TU+DMPA, possibly involved in caspase 3 activation that acted as the executor of germ cell apoptosis. In contraception, the effect of hormone is expected to be reversible in reducing the quantity and quality of spermatozoa, and this expectation was fulfilled at the end of this study (Figure 4). 
At maintenance phase, caspase 3 expression in the treatment group tended to decrease, but the decrease was not significant $(P>0,05)$ compared with the control group or pretreatment phase. Long term and repeated injections of TU+DMPA increased caspase 3 positive germ cells significantly, but the effect was reversible when injection was discontinued. Long term injections of TU+DMPA decreased caspase 3 expression possibly through hormone feed back at hypothalamushypophysis-testis axis so that intratesticular testosterone returned to normal. Repair of intratesticular testosterone level decreased caspase 3 expression in spermatogenic cells. A study revealed that testosterone might inhibit caspase-3 gene transcription and/or increase caspase-3 mRNA degradation. Although different responsive elements in rat caspase-3 gene promoter have been identified (including Sp1 and Ets-like elements), androgen responsive elements in this promoter were not present suggesting a possible indirect control of androgens on caspase- 3 gene promoter. This suggested that androgen action on caspase-3 gene expression involved a cascade of intermediates whose nature remains to be identified. ${ }^{10}$

Initially, caspase 3 expression was localized in spermatogonia, especially at pretreatment phase. At suppression and maintenance phases, localization of caspase 3 was at spermatocytes (Figure 2). Theoretically, cleavage activation of poly ADP-ribose polymerase (PARP) that is caspase 3 substrate might be found at spermatocytes due to decreased intratesticular testosterone effected by TU+DMPA long acting injection. Further, caspaseactivated deoxyribonuclease (CAD) at spermatocytes might induce apoptosis. Kim et al., ${ }^{6}$ revealed significantly increased cleavage of PARP during testosterone and estradiol treatment. Additionally, the caspase-activated deoxyribonuclease content was significantly increased in germ cells during testosterone and estradiol administration to rats and caspase activated deoxyribonuclease immuno-reactivity was localized to the nuclei of apoptotic spermatocytes. Taken together, these results indicated that germ cell apoptosis resulting from a reduced intratesticular testosterone concentration was caspase- 3 activation dependent, and suggested that the translocation of active caspase- 3 and caspase-activated deoxyribonuclease to the nucleus might be involved in the induction of germ cell apoptosis.

The tight inverse correlation observed between the number of caspase 3 positive spermatogenic cells and sperm concentration (Table 1, Figure 5), suggested that an execution of the genetic program required for apoptosis might be associated with an up-regulation of caspase 3 gene expression in germ cells. Increasing caspase 3 activation by long term and repeated injections of TU+DMPA might happen through negative feed back. The TU+DMPA injections induced degradation of intratesticular testosterone. In a study, examination of the testicular tissue revealed that germ cell apoptosis resulting from a reduced intratesticular testosterone concentration was caspase 3 dependent and that the translocation of active caspase 3 and caspase-activated deoxyribonuclease to the nucleus might be involved in the induction of germ cell apoptosis. ${ }^{8}$

In conclusion, long term injections of TU+ DMPA decreased sperm concentration and increased caspase 3 positive germ cells significantly. Further, significant relationship was found between caspase-3-positive germ cells and decreasing sperm concentration during long term and repeated injections of TU+DMPA.

\section{Acknowledgments}

We thank Dr. Farid Saad from Schering AG Germany for giving the testosterone undecanoate preparations. We also thank RUT XII team from the ministry of Research and Technology - Republic of Indonesia for funding this study.

\section{REFERENCES}

1. Zhang GY, Gu YQ, Wang XH, Cui YG, Bremner WJ. A clinical trial of injectable testosterone undecanoate as a potential male contraceptive in normal Chinese men. J Clin Endocrinol Metab. 1999; 84: 3642-7.

2. Gu YQ, Tong JS, Ma DZ, Wang XH, Yuan D, Tang WH, et al. Male hormonal contraception: Effects of injections of testosterone undecanoate and depo medroxyprogesterone acetate at eight-week intervals in Chinese men. The Journal of Clinical Endocrinology \& Metabolism. 2004; 89(5):2254-62.

3. Moeloek N, Pujianto DA, Agustin R, Arsyad KM, Waluyo $\mathrm{P}$, Prihyugiarto $\mathrm{Y}$, et al. Achieving azoospermia by injections of testosterone undecanoate alone or combined with depo medroxyprogesterone acetate in Indonesian men (Jakarta center study). In: Robaire B, Chemes H, Morales $\mathrm{CR}$, eds. Proceedings of the VIIth International Congress of Andrology; 2001 June 15-19; Montreal, USA. Italy: Medimond; 2001.p.545-50.

4. Handelsman DJ, Conway AJ, Howe CJ, Turner L, Mackey MA. Establishing the minimum effective dose and additive effects of depo progestin in suppression of human spermatogenesis by a testosterone depo. J Clin Endocrinol Metab. 1996; 81:4113-21. 
5. Meriggiola MC, Costantino A, Cerpolini C, Bremner WJ, Huebler D, Morselli-Labate AM, et al. Testosterone undecanoate maintains spermatogenic suppression induced by cyproterone acetate plus testosterone undecanoate in normal men. J Clin Endocrinol Metab. 2003; 88(12): 5818-26.

6. Kim J, Ghosh S, Weil A, Zirkin B. Caspase-3 and caspaseactivated deoxyribonuclease are associated with testicular germ cell apoptosis resulting from reduced intratesticular testosterone. Endocrinology. 2001; 142: 3809-16.

7. Cui G-H, Xu ZL, Yang ZJ, Xu YY, Xue SP. A combined regimen of gossypol plus methyltestosterone and ethinylestradiol as a contraceptive induces germ cell apoptosis and expression of its related genes in rats. Contraception. 2004; 70: $335-42$
8. Said TM, Paasch U, Glander HJ, Agarwal A. Role of caspases in male infertility. Human Reproduction Update. 2004; 10(1):39-51.

9. Tesarik J, Martinez F, Rienzi L, Iacobelli M, Ubaldi F, Mendoza C, et al. In-vitro effects of FSH and testosterone withdrawal on caspase activation and DNA fragmentation in different cell types of human seminiferous epithelium. Hum Reprod. 2002; 17,1811-9.

10. Omezzine A, Mauduit C, Tabone E, Nabli N, Bouslama A, Benahmed M. Caspase- 3 and -6 expression and activation are targeted by hormone action in the rat ventral prostate during the apoptotic cell death process. ePublished on April 30, 2003. Doi: 10.1095/Biolreprod.102.012435. 